\title{
PENGARUH BUDAYA ORGANISASI DAN IKLIM KOMUNIKASI ORGANISASI TERHADAP LOYALITAS PENGURUS
}

\author{
(Studi Kuantitatif Pada Komunitas Young On Top Bandung)
}

\author{
Auliya Khairina Nurri, Ayub Ilfandy Imran \\ Fakultas Komunikasi dan Bisnis, Universitas Telkom \\ email: nurriauliya@gmail.com \\ Fakultas Komunikasi dan Bisnis, Universitas Telkom \\ email: a_ilfandy@yahoo.com
}

\begin{abstract}
ABSTRAK
Young On Top Bandung merupakan komunitas yang berfokus kepada pengembangan potensi generasi muda secara skill, knowledge, dan attitude. Tujuan dilakukannya penelitian ini adalah untuk mengetahui besarnya pengaruh budaya organisasi dan iklim komunikasi organisasi secara simultan dan parsial terhadap loyalitas pengurus pada komunitas Young On Top Bandung. Penelitian ini menggunakan metode kuantitatif dengan jenis penelitian berupa asosiatif. Pengambilan sampel dilakukan dengan metode non-probability sampling jenis sampling jenuh, dengan jumlah responden sebanyak 67 orang. Teknik analisis data yang digunakan adalah analisis deskriptif dan analisis regresi linier berganda. Berdasarkan hasil pengujian hipotesis secara simultan, budaya organisasi dan iklim komunikasi organisasi secara bersama-sama berpengaruh signifikan terhadap loyalitas pengurus komunitas Young On Top Bandung. Dimana koefisien determinasi yang didapat adalah sebesar 72,2\%. Hal ini menunjukkan bahwa Pengaruh Budaya Organisasi dan Iklim Komunikasi Organisasi terhadap Loyalitas Pengurus secara simultan (bersama-sama) memberikan pengaruh sebesar 72,2\% sedangkan sisanya 27,8\% dipengaruhi oleh faktor variabel lain selain Budaya Organisasi dan Iklim Komunikasi Organisasi.
\end{abstract}

Kata kunci: Budaya Organisasi, Iklim Komunikasi Organisasi, Loyalitas Pengurus

\begin{abstract}
Young On Top Bandung is a community that focuses on developing the potential of young generation in skill, knowledge, and attitude. The purpose of this study was to determine the influence of organizational culture and organizational communication climate on organizer loyalty at Young On Top Bandung community. This study uses quantitative associative research. Sampling technique used was jenuh sampling type under non-probability sampling, with the total number of 67 respondents. The data was analyzed descriptively, and the hypothesis were tested by using multiple linear regression analysis. Based on the results of simultaneous hypothesis testing, organizational culture and organizational communication climate significantly influence organizer loyalty at Young On Top Bandung community. Based on the coefficient of determination, obtained value is 72,2\%. The results showed that the effect of Organizational Culture and Organizational Communication Climate on Organizer Loyalty simultaneously gave the effect of 72,2\% and the remaining 27,8\% was influenced by other factors beside Organizational Culture and Climate Organizational Communication.
\end{abstract}

Keyword: Organizational Culture, Organizational Communication Climate, Organizer Loyalty 


\section{PENDAHULUAN}

Salah satu komunitas penggerak yang menjadi wadah bagi anak muda untuk meraih kesuksesan diusianya yang masih muda ialah komunitas Young On Top Bandung. Komunitas Young On Top sendiri awalnya terbentuk karena terinspirasi dari buku yang berjudul sama yaitu "Young On Top" karangan Billy Boen. Komunitas Young On Top Bandung berfokus kepada pengembangan potensi generasi muda baik secara skill, knowledge, dan attitude dimana dalam komunitas ini mengembangkan soft skill diri dari berbagai bidang yang mengajarkan kepada banyak hal untuk dapat sukses, tidak hanya menjadi pemimpin, berbisnis atau berwirausaha namun juga berekspresi, melakukan kegiatan sosial, pelatihan, serta mengadakan event-event yang ada di Bandung.

Banyaknya komunitas sejenis tentunya menimbulkan bentuk persaingan tersendiri dalam menarik anggota maupun pengurus agar tetap terjalannya fungsi dan tujuan dari komunitas tersebut. Hal ini menjadi tantangan tersendiri bagi komunitas untuk mempertahankan pengurus mengingat banyaknya komunitas sejenis yang berkembang dan bermunculan. Disinilah peran budaya dalam komunitas dibutuhkan, suatu komunitas dapat menjadi unggul apabila mempunyai budaya yang kuat dengan karakter nilai yang tinggi sehingga dapat disosialisasikan kepada setiap pengurus agar nilai komunitas dan nilai pengurus dapat bersatu. Budaya organisasi yang dibangun dan ditanamkan harus mampu mendorong para pengurus dalam komunitas memiliki tujuan, persepsi, komitmen, nilai dan kepercayaan. Budaya organisasi memiliki keterhubungan dengan iklim komunikasi organisasi. Dimana iklim komunikasi organisasi dapat berupa sifat dari budaya organisasi. Iklim komunikasi berperan dalam keutuhan suatu budaya dan membimbing perkembangan budaya tersebut.

Budaya organisasi dan iklim komunikasi organisasi tidak akan terasa tanpa hadirnya pengurus yang ada dalam organisasi. Suatu komunitas akan berjalan dan mencapai tujuannya jika terdapat pengurus yang memiliki loyalitas tinggi didalamnya. Karena penguruslah yang memiliki hubungan intens dengan komunitas dan terlibat secara langsung dalam setiap kegiatan komunitas. Pemahaman akan budaya organisasi dan iklim komunikasi organisasi merupakan sarana terbaik untuk penyesuaian pengurus agar merasa nyaman dan bertanggungjawab sehingga timbul sifat loyalitas dalam diri pengurus. Berdasarkan masalah yang telah dipaparkan diatas, peneliti tertarik untuk melakukan penelitian dengan judul "PENGARUH BUDAYA ORGANISASI DAN IKLIM KOMUNIKASI ORGANISASI TERHADAP LOYALITAS PENGURUS (Studi Kuantitatif Pada Komunitas Young On Top Bandung)".

\section{Identifikasi Masalah}

Peneliti menetapkan identifikasi masalah berdasarkan rumusan masalah yang di antaranya adalah:

1) Seberapa besar pengaruh budaya organisasi di komunitas Young On Top Bandung?

2) Seberapa besar pengaruh iklim komunikasi organisasi di komunitas Young On Top Bandung?

3) Seberapa besar pengaruh loyalitas pengurus pada komunitas Young On Top Bandung?

4) Seberapa besar pengaruh budaya organisasi dan iklim komunikasi organisasi secara simultan maupun parsial terhadap loyalitas pengurus komunitas Young On Top Bandung?

\section{Tujuan Penelitian}

Berdasarkan identifikasi masalah tersebut, maka tujuan penelitian dapat dijabarkan sebagai berikut:

1) Untuk mengetahui seberapa besar pengaruh budaya organisasi di komunitas Young On Top Bandung.

2) Untuk mengetahui seberapa besar iklim komunikasi organisasi di komunitas Young On Top Bandung. 
3) Untuk mengetahui seberapa besar loyalitas pengurus pada komunitas Young On Top Bandung.

4) Untuk mengetahui seberapa besar pengaruh budaya organisasi dan iklim komunikasi organisasi secara simultan maupun parsial terhadap loyalitas pengurus komunitas Young On Top Bandung.

\section{KAJIAN LITERATUR}

Adapun kajian literatur yang digunakan dalam penelitian ini ialah:

1) Komunikasi Organisasi

Menurut Sendjaja, 1994 (dalam Suryanto, 2015:320), komunikasi organisasi pada umumnya membahas struktur dan fungsi organisasi, hubungan antarmanusia, komunikasi dan proses pengorganisasian serta budaya organisasi. Komunikasi organisasi diberi batasan sebagai arus pesan dalam suatu jaringan yang sifatnya saling bergantung satu sama lain meliputi arus komunikasi vertikal dan horizontal.

2) Budaya Organisasi

Menurut Wirawan (2008:10), budaya organisasi merupakan norma, nilai-nilai, asumsi, kepercayaan, filsafat, kebiasaan organisasi, dan sebagainya (isi budaya organisasi) yang dikembangkan dalam waktu yang lama oleh pendiri, pemimpin, dan anggota organisasi yang disosialisasikan dan diajarkan kepada anggota baru serta diterapkan dalam aktivitas organisasi sehingga memengaruhi pola pikir, sikap, dan perilaku anggota organisasi dalam mencapai tujuan organisasi.

3) Iklim Komunikasi Organisasi

Menurut Redding, 1972 (dalam Pace dan Faules, 2006:154), iklim komunikasi organisasi merupakan fungsi kegiatan yang terdapat dalam organisasi untuk menunjukkan kepada pengurus organisasi bahwa organisasi tersebut mempercayai mereka dan memberi mereka kebebasan dalam mengambil resiko; mendorong mereka dan memberi mereka tanggung jawab dalam mengerjakan tugas- tugas mereka; menyediakan informasi yang terbuka dan cukup tentang organisasi; mendengarkan dengan penuh perhatian serta memperoleh informasi yang dapat dipercayai dan terus terang dari pengurus organisasi; secara aktif memberi penyuluhan kepada para pengurus organisasi sehingga mereka dapat melihat bahwa keterlibatan mereka penting bagi keputusan-keputusan dalam organisasi; dan menaruh perhatian pada pekerjaan yang bermutu tinggi dan memberi tantangan.

4) Loyalitas Pengurus

Menurut Oetomo, 2006 (dalam Novira, 2012:34), loyalitas adalah sense of responsibility, bukan hanya tanggung jawab saja tetapi juga perasaan yang lebih daripada tanggung jawab menjalankan perintah atasan, itu bukan hanya sekedar menjalankan perintah, tetapi juga dapat memberikan masukan yang berarti dan terbaik untuk perusahaan.

\section{Hipotesis}

Adapun hipotesis dalam penelitian ini adalah:

$\mathrm{H}_{01}$ :Tidak terdapat pengaruh yang signifikan antara budaya organisasi terhadap loyalitas pengurus di komunitas Young On Top Bandung.

$\mathrm{H}_{11}$ :Terdapat pengaruh yang signifikan antara budaya organisasi terhadap loyalitas pengurus di komunitas Young On Top Bandung.

$\mathrm{H}_{02}$ :Tidak terdapat pengaruh yang signifikan antara iklim komunikasi organisasi terhadap loyalitas pengurus di komunitas Young On Top Bandung.

$\mathrm{H}_{12}$ :Terdapat pengaruh yang signifikan antara iklim komunikasi organisasi terhadap loyalitas pengurus di komunitas Young On Top Bandung.

$\mathrm{H}_{03}$ :Tidak terdapat pengaruh yang signifikan antara budaya organisasi dan iklim komunikasi organisasi terhadap loyalitas pengurus di komunitas Young On Top Bandung. 
$\mathrm{H}_{13}$ :Terdapat pengaruh yang signifikan antara budaya organisasi dan iklim komunikasi organisasi terhadap loyalitas pengurus di komunitas Young On Top Bandung.

\section{METODE PENELITIAN}

Metode penelitian yang peneliti gunakan adalah metode penelitian studi kuantitatif. Menurut Sugiyono (2012:11), metode kuantitatif merupakan metode penelitian yang berlandaskan pada filsafat positivisme, digunakan untuk meneliti pada populasi atau sampel tertentu, pengumpulan data menggunakan instrumen penelitian, analisis data bersifat kuantitatif/statistik, dengan tujuan untuk menguji hipotesis yang telah ditetapkan.

Penelitian ini mengungkapkan hubungan dari variabel-variabel yang ada, dimana pada penelitian ini terdapat dua variabel independen (variabel yang mempengaruhi), dan variabel dependen (variabel yang dipengaruhi). Tujuan dari penelitian ini untuk mengetahui pengaruh budaya organisasi dan iklim komunikasi terhadap loyalitas pengurus di komunitas Young On Top Bandung.

Teknik pengumpulan data yang peneliti gunakan ialah kuesioner, dimana sumber data kuesioner diperoleh dari responden komunitas Young On Top Bandung. Adapun teknik analisis data yang peneliti gunakan ialah analisis deskriptif dan analisis regresi linear berganda. Penelitian ini berlokasi di Bandung dengan waktu penelitian dimulai dari bulan agustus 2017 hingga desember 2017.

\section{HASIL DAN PEMBAHASAN}

1) Analisis Deskriptif Responden Budaya Organisasi $\left(\mathbf{X}_{1}\right)$

Setiap organisasi pasti memiliki budaya organisasi tersendiri yang dapat memengaruhi aspek organisasi dan perilaku pengurusnya secara individu maupun kelompok. Budaya organisasi memiliki beberapa karakteristik utama yang secara keseluruhan menjadi elemen-elemen penting dalam suatu organisasi. Menurut Robbins (2002:279), diantaranya ialah inovasi dan keberanian mengambil resiko, orientasi terhadap individu, dan orientasi terhadap tim. Ketiga karakteristik tersebut menunjukkan karakteristik budaya organisasi yang dapat memengaruhi sikap dan perilaku anggota komunikasi yang kemudian menentukan kinerja pengurus yang nantinya juga berdampak terhadap loyalitas pengurus di organisasi.

\section{Tabel 1. Rekapitulasi Tanggapan Responden Mengenai Budaya Organisasi $\left(\mathbf{X}_{1}\right)$}

\begin{tabular}{|c|c|c|c|}
\hline No & Dimensi & $\begin{array}{l}\text { Skor } \\
\text { Total }\end{array}$ & $\%$ \\
\hline 1 & $\begin{array}{c}\text { Inovasi dan Keberanian } \\
\text { mengambil resiko }\end{array}$ & 851 & $79.4 \%$ \\
\hline 2 & Orientasi terhadap Individu & 881 & $82.2 \%$ \\
\hline 3 & Orientasi terhadap tim & 804 & $75.0 \%$ \\
\hline & Jumlah Skor Total & \multicolumn{2}{|c|}{2536} \\
\hline & Persentase & \multicolumn{2}{|c|}{$78.9 \%$} \\
\hline
\end{tabular}

Berdasarkan hasil analisis deskriptif, budaya organisasi komunitas Young On Top Bandung secara keseluruhan termasuk kedalam kategori baik dimata pengurus komunitas. Dari 12 pernyataan yang disebarkan dalam kuesioner, variabel Budaya Organisasi $\left(\mathrm{X}_{1}\right)$ mendapat skor sebesar 78,9\%. Hal ini menunjukkan bahwa budaya organisasi di komunitas Young On

Top Bandung itu tinggi. Peneliti mendapati bahwa Indikator Orientasi terhadap Individu memiliki persentase skor paling tinggi yaitu $82,2 \%$, diikuti oleh indikator Inovasi dan Keberanian Mengambil Resiko dengan persentase skor $79,4 \%$, dan yang terakhir adalah indikator Orientasi terhadap Tim dengan persentase skor $75,0 \%$. Hal ini menunjukkan bahwa komunitas Young On Top Bandung telah berhasil menciptakan budaya organisasi yang tinggi seperti, berinovasi dan berani mengambil resiko, berorientasi terhadap individu, dan berorientasi terhadap tim.

\section{2) Analisis Deskriptif Responden Iklim Komunikasi Organisasi $\left(\mathbf{X}_{2}\right)$ \\ Budaya organisasi memiliki keterhubungan} dengan iklim komunikasi organisasi. Dimana iklim komunikasi organisasi dapat berupa sifat dari budaya organisasi. Iklim berperan dalam 
keutuhan suatu budaya dan membimbing perkembangan budaya tersebut sehingga iklim juga ikut bertindak dalam memengaruhi loyalitas pengurus.

Tabel 2. Rekapitulasi Tanggapan Responden Mengenai Iklim Komunikasi Organisasi $\left(\mathbf{X}_{2}\right)$

\begin{tabular}{|c|c|c|c|}
\hline No & Dimensi & $\begin{array}{c}\text { Skor } \\
\text { Total }\end{array}$ & \% \\
\hline 1 & Kepercayaan & 643 & $80.0 \%$ \\
\hline 2 & $\begin{array}{c}\text { Pembuat Keputusan } \\
\text { bersama }\end{array}$ & 621 & $77.2 \%$ \\
\hline 3 & Kejujuran & 615 & $76.5 \%$ \\
\hline 4 & $\begin{array}{c}\text { Perhatian pada tujuan- } \\
\text { tujuan berkinerja tinggi }\end{array}$ & 570 & $70.9 \%$ \\
\hline & Jumlah Skor Total & \multicolumn{2}{|c|}{$\mathbf{2 4 4 9}$} \\
\hline & Persentase & \multicolumn{2}{|c|}{$\mathbf{7 6 . 2 \%}$} \\
\hline
\end{tabular}

Berdasarkan hasil analisis deskriptif, iklim komunikasi organisasi komunitas Young On Top Bandung secara keseluruhan termasuk kedalam kategori baik dimata pengurus komunitas. Dari 12 pernyataan yang disebarkan dalam kuesioner, variabel Iklim Komunikasi Organisasi mendapat skor sebesar $76.2 \%$. Hal ini menunjukkan bahwa iklim komunikasi organisasi di komunitas Young On Top Bandung itu tinggi. Peneliti mendapati bahwa indikator Kepercayaan memiliki persentase skor paling tinggi yaitu $80,0 \%$, diikuti oleh indikator Pembuat Keputusan Bersama dengan persentase skor $77,2 \%$, lalu ditempat ketiga diikuti oleh indikator Kejujuran dengan persentase skor $76,5 \%$, dan yang terakhir adalah indikator Perhatian pada tujuan-tujuan berkinerja tinggi dengan persentase skor 70,9\%. Hal ini menunjukkan bahwa komunitas Young On Top Bandung telah berhasil menciptakan iklim komunikasi organisasi yang tinggi seperti, kepercayaan, pembuat keputusan bersama, kejujuran, dan perhatian pada tujuan-tujuan yang berkinerja tinggi. Sejalan dengan iklim komunikasi organisasi menurut Redding, 1972 (dalam Pace dan Faules, 2006:154) yaitu fungsi kegiatan yang terdapat dalam organisasi untuk menunjukkan kepada pengurus organisasi bahwa organisasi mempercayai mereka, mendengarkan dengan penuh penuh perhatian, secara aktif memberi penyuluhan kepada para pengurus sehingga mereka dapat melihat bahwa keterlibatan mereka penting bagi keputusankeputusan dalam organisasi.

\section{3) Analisis Deskriptif Responden Loyalitas Pengurus (Y) \\ Menurut Sudimin, 2003 (dalam Novira,} 2012:33), loyalitas merupakan kesediaan karyawan dengan seluruh kemampuan, keterampilan, pikiran dan waktu untuk ikut serta mencapai tujuan perusahaan dan menyimpan rahasia perusahaan serta tidak melakukan tindakan-tindakan yang merugikan perusahaan selama orang itu masih berstatus sebagai karyawan. Sejalan dengan karyawan, pengurus pun juga akan bersedia untuk mencapai tujuan komunitas dan tidak melakukan tindakan yang akan merugikan komunitas saat pengurus juga memiliki loyalitas terhadap komunitasnya. Loyalitas pengurus dapat dilihat dari bagaimana sikap dan perilaku pengurus dalam berinteraksi di komunitas.

\section{Tabel 3. Rekapitulasi Tanggapan Responden Mengenai Loyalitas Pengurus (Y)}

\begin{tabular}{|c|c|c|c|}
\hline No & Dimensi & $\begin{array}{c}\text { Skor } \\
\text { Total }\end{array}$ & $\%$ \\
\hline 1 & Taat pada peraturan & 598 & $74.4 \%$ \\
\hline 2 & $\begin{array}{c}\text { Kemauan untuk bekerja } \\
\text { sama }\end{array}$ & 620 & $77.1 \%$ \\
\hline 3 & Rasa memiliki & 609 & $75.7 \%$ \\
\hline 4 & Hubungan antar Pribadi & 654 & $81.3 \%$ \\
\hline 5 & $\begin{array}{c}\text { Kesukaan terhadap } \\
\text { Pekerjaan }\end{array}$ & 691 & $85.9 \%$ \\
\hline \multicolumn{2}{|c|}{ Jumlah Skor Total } & \multicolumn{2}{|c|}{3172} \\
\hline \multicolumn{2}{|c|}{ Persentase } & \multicolumn{2}{|c|}{$78.9 \%$} \\
\hline
\end{tabular}

Berdasarkan hasil analisis deskriptif, Loyalitas Pengurus Komunitas Young On Top Bandung secara keseluruhan berada dalam kategori baik. Hal ini terlihat dari jawaban responden terhadap 15 pernyataan yang disebarkan dalam kuesioner, variabel Loyalitas Pengurus memperoleh persentase sebesar $78.9 \%$ masuk dalam kategori tinggi. Dari lima indikator yang ada pada variabel loyalitas pengurus yang 
mendapat nilai tertinggi dengan persentase sebesar $85.9 \%$ terdapat pada indikator Kesukaan terhadap Pekerjaan. Hal ini menunjukkan bahwa pengurus komunitas bersungguh-sungguh di dalam komunitas Young On Top Bandung, tidak menuntut imbalan apapun selama mengikuti komunitas ini, dan selalu berusaha memberikan yang terbaik untuk komunitas. Selanjutnya diikuti oleh indikator Hubungan antar Pribadi dengan persentase skor $81,3 \%$. Ditempat ketiga diikuti oleh indikator Kemauan untuk bekerja sama dengan persentase skor $77,1 \%$. Lalu ditempat keempat diikuti oleh indikator Rasa Memiliki dengan persentase skor $75,7 \%$. Dan yang terakhir adalah indikator Taat pada peraturan dengan persentase skor $74,4 \%$.

\section{4) Pengaruh Budaya Organisasi dan Iklim Komunikasi Organisasi Secara Simultan dan Parsial Terhadap Loyalitas Pengurus}

Dari hasil perhitungan koefisien determinasi menunjukkan bahwa nilai yang didapat dari $\mathrm{R}$ Square $\left(\mathrm{R}^{2}\right)$ adalah sebesar 0,722 atau $72,2 \%$. Hal tersebut menunjukkan bahwa Pengaruh Budaya Organisasi $\left(\mathrm{X}_{1}\right)$ dan Iklim Komunikasi Organisasi $\left(\mathrm{X}_{2}\right)$ terhadap Loyalitas Pengurus (Y) secara simultan (bersama-sama) memberikan pengaruh sebesar $72,2 \%$ sedangkan sisanya $27,8 \%$ dipengaruhi oleh faktor variabel lain selain Budaya Organisasi $\left(\mathrm{X}_{1}\right)$ dan Iklim Komunikasi Organisasi $\left(\mathrm{X}_{2}\right)$ yang tidak diteliti.

Budaya Organisasi $\left(\mathrm{X}_{1}\right)$ dan Iklim Komunikasi Organisasi $\left(\mathrm{X}_{2}\right)$ secara bersamasama atau simultan berpengaruh signifikan terhadap Loyalitas Pengurus (Y) dapat dilihat dari hasil uji $\mathrm{F}$ dimana $\mathrm{F}_{\text {hitung }}$ adalah sebesar 83,233 lebih besar dari $F_{\text {tabel }}$ sebesar 3,140. Sehingga $F_{\text {hitung }}(83,233)>F_{\text {tabel }}(3,140)$. $)$ dengan tingkat signifikansinya $0,000<0,005$. Hal ini menunjukkan bahwa terdapatnya pengaruh yang signifikan antara budaya organisasi dan iklim komunikasi organisasi terhadap loyalitas pengurus komunitas.

Sedangkan Budaya Organisasi $\left(\mathrm{X}_{1}\right)$ dan Iklim Komunikasi Organisasi $\left(\mathrm{X}_{2}\right)$ secara parsial berdasarkan uji t menunjukkan bahwa Variabel
$\mathrm{X}_{1}$ memiliki nilai $\mathrm{t}_{\text {hitung }}$ lebih besar dari nilai $\mathrm{t}_{\text {tabel }}$. Karena nilai $t_{\text {hitung }}(5,190)>t_{\text {tabel }}(1,998)$, maka dapat disimpulkan bahwa secara parsial terdapat pengaruh signifikan dari Budaya Organisasi $\left(\mathrm{X}_{1}\right)$ terhadap Loyalitas Pengurus (Y). Sedangkan besarnya pengaruh Budaya Organisasi $\left(\mathrm{X}_{1}\right)$ terhadap Loyalitas Pengurus (Y) secara parsial adalah $47,6 \%$.

Untuk variabel $\mathrm{X}_{2}$ memiliki nilai $\mathrm{t}_{\text {hitung }}$ lebih besar dari nilai $t_{\text {tabel }}$. Karena nilai $t_{\text {hitung }}(2,856)>$ $t_{\text {tabel }}(1,998)$, maka dapat disimpulkan bahwa secara parsial terdapat pengaruh signifikan dari Iklim Komunikasi Organisasi $\left(\mathrm{X}_{2}\right)$ terhadap Loyalitas Pengurus (Y). Sedangkan besarnya pengaruh Iklim Komunikasi Organisasi $\left(\mathrm{X}_{2}\right)$ terhadap Loyalitas Pengurus (Y) secara parsial adalah $24,6 \%$.

\section{Kesimpulan}

Berdasarkan hasil penelitian mengenai Pengaruh Budaya Organisasi dan Iklim Komunikasi Organisasi Terhadap Loyalitas Pengurus di Komunitas Young On Top Bandung dapat ditarik kesimpulan sebagai berikut:

1) Berdasarkan hasil analisis deskriptif, Budaya Organisasi di mata responden secara keseluruhan berada dalam kategori tinggi dengan garis kontinum total yaitu mendapat skor sebesar 78,9\%.

2) Berdasarkan hasil analisis deskriptif, Iklim Komunikasi Organisasi di mata responden secara keseluruhan berada dalam kategori tinggi dengan garis kontinum total yaitu mendapat skor sebesar $76,2 \%$.

3) Berdasarkan hasil analisis deskriptif, Loyalitas Pengurus pada komunitas Young On Top Bandung termasuk dalam kategori tinggi dimana garis kontinum total yaitu mendapat skor sebesar 78,9\%.

4) Pada hasil penelitian, peneliti mendapati bahwa besar pengaruh Budaya Organisasi dan Iklim Komunikasi Organisasi secara simultan terhadap Loyalitas Pengurus Komunitas Young On Top Bandung ialah sebesar $72,2 \%$. Hal ini menunjukkan bahwa Pengaruh Budaya Organisasi $\left(\mathrm{X}_{1}\right)$ dan Iklim Komunikasi Organisasi $\left(\mathrm{X}_{2}\right)$ terhadap 
Loyalitas Pengurus (Y) secara simultan (bersama-sama) memberikan pengaruh sebesar $72,2 \%$ sedangkan sisanya $27,8 \%$ dipengaruhi oleh faktor variabel lain selain Budaya Organisasi $\left(\mathrm{X}_{1}\right)$ dan Iklim Komunikasi Organisasi $\left(\mathrm{X}_{2}\right)$ yang tidak diamati dalam penelitian ini. Secara parsial, diketahui besar pengaruh budaya organisasi terhadap loyalitas pengurus komunitas ialah sebesar $47,6 \%$ dan besar pengaruh iklim komunikasi organisasi terhadap loyalitas pengurus komunitas secara parsial ialah sebesar $24,6 \%$.

\section{Saran}

Berdasarkan hasil simpulan yang telah diuraikan di atas, peneliti dapat memberikan beberapa saran yang diharapkan dapat bermanfaat bagi pihak Komunitas Young On Top Bandung dan peneliti selanjutnya, yaitu:

\section{1) Saran Akademis}

Adapun saran bagi penelitian selanjutnya yaitu:

a. Diharapkan dapat memperluas objek penelitiannya dengan sampel yang lebih besar sehingga dapat memberikan penelitian yang lebih mewakilkan komunitas yang diteliti.

b. Diharapkan dapat mengembangkan penelitian ini dengan menambahkan variabel yang belum diteliti yang kemungkinan dapat berpengaruh pada komunitas Young On Top Bandung.

c. Diharapkan melakukan penelitian pada komunitas sejenis sehingga hasil dari penelitian tersebut dapat dijadikan bahan perbandingan.

\section{2) Saran Praktis}

Adapun saran bagi komunitas Young On Top Bandung yaitu:

a. Melihat rendahnya nilai Orientasi terhadap tim dari ketiga tanggapan responden mengenai Budaya Organisasi, diharapkan pengurus dapat menjaga ketepatan waktu di setiap kegiatan komunitas agar terjalinnya rasa saling menghargai antar sesama pengurus. Sesuai dengan 35 Kunci Sukses
Young On Top yang dipercaya sebagai jalan sukses di usia muda.

b. Diharapkan pengurus lebih bertindak aktif di komunitas, meningkatkan dan mempertahankan hubungan yang harmonis dan akrab serta menjaga kekompakkan antar pengurus komunitas baik di dalam maupun di luar komunitas.

c. Melihat rendahnya nilai Perhatian pada tujuan-tujuan berkinerja tinggi dari keempat tanggapan responden mengenai Iklim Komunikasi Organisasi, diharapkan pengurus memiliki loyalitas yang tinggi dalam mengikuti kegiatan dengan hadir pada setiap kegiatan komunitas yang diadakan agar dapat terjalannya fungsi kegiatan dengan baik.

Melihat rendahnya nilai Taat pada peraturan dari kelima tanggapan responden mengenai Loyalitas Pengurus, diharapkan pengurus dapat meningkatkan kedisiplinan sesuai dengan aturan yang telah ditetapkan dalam komunitas.

\section{Referensi}

\section{A. Buku}

Pace, R. Wayne. \& Faules, Don. F. (2006). Komunikasi Organisasi: Strategi Meningkatkan Kinerja Perusahaan (editor Deddy Mulyana, M.A., PH.D.). Bandung: PT Remaja Rosdakarya.

Sugiyono (2012). Metode Penelitian Kombinasi (Mixed Methods). Bandung: Alfabeta.

Suryanto (2015). Pengantar Ilmu Komunikasi. Bandung: Pustaka Setia.

Wirawan (2008). Budaya dan Iklim Organisasi: Teori Aplikasi dan Penelitian. Jakarta: Salemba Empat.

Robbins, Stephen P. (2002). Prinsip-prinsip Perilaku Organisasi (Edisi Kelima). Jakarta: Erlangga.

\section{B. Jurnal}

Novira, Riny. (2012). Analisis Pengaruh Gaya Kepemimpinan, Komunikasi Organisasi, dan Jenis Penghargaan Terhadap Loyalitas Karyawan. Jakarta: Universitas Bina Nusantara. 
Vol. 1, No. 1, April 2018 